\title{
Learning from Experience? Second-Order Policy Devolution and Government Responsiveness
}

\author{
Susan WebB YackeE \& Christine Kelleher Palus
}

\begin{abstract}
Proponents of devolution often claim that the decentralization of policymaking authority to sub-national governments generates better outcomes because decision-making takes place "closer to the people". Yet, the theoretical rationale for why devolution might improve outcomes often remains unspecified. We unpack this argument by formally stating one causal relationship that is often left implicit-devolution leads to experimentation, learning by administrators, and better policy outcomes. We then offer an exploratory empirical examination of this argument. We utilize data collected after the decentralization of welfare-related policymaking authority to local leaders in one American state, North Carolina. We employ case studies, survey research, and budgetary data from 1998 to 2003. Our findings suggest that while some experimentation did occur as a result of devolution, local officials in North Carolina rarely replicated policy decisions that led to improved outcomes in their communities. We conclude that a key argument used to advance policy devolution across a number of countries and political regimes is in need of reevaluation and, potentially, revision.
\end{abstract}

KEYwords: - federalism • devolutin • decentralisation • selfgovernance $\bullet$ policy learning $\bullet$ North Carolina

Correspondence Address: Susan Webb Yackee, Ph.D., La Follette School of Public Affairs, University of Winsconsin - Madison, 1225 Observatory Drive, Madison, WI 53706, USA, e-mail: syackee@lafollette.edu. Christine Kelleher Palus, Ph.D., Department of Political Science, Villanova University College of Liberal Arts and Sciences, St. Augustine Ctr Liberal Arts Rm 261, Political Science, 800 Lancester Avenue, Villanova, PA 19085, USA, e-mail: christine.palus@villanova.edu. 


\section{Introduction}

Scholars of political science, public administration, and public policy often debate which level of government can best provide services to its citizens. Within this debate, some federalism scholars and select politicians suggest that the transfer of power to sub-national governments delegates policy choices to officials more in tune with local norms and values (Murray, 1984; Osborne, 1988; Eggers \& O'Leary, 1995; Kincaid, 1998). Frequently, the tacit assumption linked with this argument is that devolution provides local leaders the necessary flexibility to create new and innovative programs to address their community's problems more successfully. Surprisingly, however, the extant American and cross-national literatures provide relatively few answers regarding the effectiveness of devolution in addressing problems in sub-national governments (Scully, Jones, \& Trystan, 2004; Soss et al., 2001; Mettler, 2000; Winston, 2002). It is to this gap in our understanding of self-governance that we address this article.

In short, we lack a full understanding regarding the connection between the legislative act of devolution and the administrative execution of new policy. The comparative politics perspective frequently frames the initial act of devolution as a strategic one driven by the motivations of the political party in control (Sawyer, 1969; O’Neill, 1999; Garman, Haggard \& Willis 2001), while scholars such as Conlan (1998) and Walker (2000) provide rich historical accounts of why American policymakers including Nixon, Reagan, and Gingrich chose to pursue a legislative strategy that included devolution. Yet, there is little work detailing the linkages between devolved authority and policy outcomes in sub-national governments. The primary contribution of this article is its unpacking of one causal argument used implicitly in support of devolution. This line of argumentation follows: devolution $\rightarrow$ policy experimentation $\rightarrow$ internal learning $\rightarrow$ better outcomes. ${ }^{1}$

We also provide an exploratory empirical investigation into the veracity of this argument. We turn to the implementation of welfare reform in one American state, North Carolina, to serve as a "crucial case" (Eckstein, 1975) for assessing the argument. In 1997, North Carolina was one of eight states to devolve a significant amount of welfare-related policymaking authority from the state to its counties (Gainsborough, 2003), and according to Cooke and Haithcock (2002), sub-national officials in North Carolina were well-equipped to take advantage of the new policymaking discretion in their jurisdictions. North Carolina's county social services employees generally had high levels of administrative capacity, were well educated, and already had significant policymaking experience in the area of social policy well before the enactment of the state's 1997 welfare reform legislation (Cooke \& Haithcock, 2002). Thus, we use a "most likely" (Eckstein, 1975) empirical case: a case tilted toward finding evidence of a connection 
between devolved policymaking authority, learning, and improved policy outcomes.

We hypothesize that devolution provides an opportunity for sub-national officials to "learn" to replicate programming that yields successful outcomes via their internal policy experimentation. First, we first test this hypothesis by first identifying the type of programmatic spending that was positively linked to improved outcomes on a major welfare-related goal-decreasing welfare caseloads. We specifically investigate spending in two programmatic spending areas - childcare and transportation. Second, we then look for trends in descriptive spending patterns that suggest whether, or not, county leaders "learned" in subsequent years to replicate policy decisions that improved outcomes related to decreasing welfare caseloads. To our knowledge, this research design represents the first effort to quantitatively assess one of the primary rationales used to promote policy devolution.

We find, in short, little preliminary evidence in support of the argument that second-order devolution leads to reductions in welfare caseloads as a result of internal policy learning in this empirical case study. Stated differently, while some progress toward welfare-related goals may have been accomplished in North Carolina counties, this progress does not appear to be driven by the replication of successful policy innovations enabled by policymaking being "closer to the people." However, some prudence is merited when interpreting these preliminary results. The study's research design, and particularly its focus on one welfarerelated goal and the budgetary decision-making within two programmatic areas, affects its generalizability. Thus, we consider these results as suggestive or preliminary in nature, as opposed to confirmative evidence. With these caveats in mind, the results remain noteworthy because they cast doubt on a key line of political reasoning frequently used to advance devolution across a number of countries and regimes. We conclude that policy scholars as well as the lawmakers responsible for devolution must now reevaluate and, potentially, revise one of the often-implicit arguments used in its support.

\section{Theoretical Foundations}

As Mohr (1969: 111) summarizes in his study of public agencies, "Innovation is suggested to be the function of an interaction among the motivation to innovate, the strength of obstacles against innovation, and the availability of resources for overcoming such obstacles". Both first-order devolution (national to state government) and second-order devolution (state to local governments) fit squarely within Mohr's definition and provide an ideal setting for innovations to occur. In fact, some scholars have argued that devolution should be pursued precisely because of its ability to spur policy experimentation and innovation (Osborne, 1988; see also Volden, 1997; Gallup-Black, 1998). However, there is a general 
disconnect in our understanding of the link between devolution, experimentation/ innovation, and policy learning. Moreover, this gap in our knowledge remains despite recent scholarly attention, particularly in the context of policy devolution and decentralization in the United Kingdom (e.g., Scully, Jones \& Trystan, 2004; Jeffery \& Wincott, 2006; Curtice, 2006; Jeffery, 2006; Mitchell, 2006).

\section{Devolution}

Lieberman and Shaw (2000) highlight two separate frameworks for understanding devolution. The first framework indicates that the decentralization of policymaking authority is primarily economic, with sub-national governments responding to their changing constituencies by providing a different mix of government services and benefits (Tiebout, 1956). Under this theoretical approach, devolution may encourage policy experimentation and innovation at the sub-national level. Moreover, the expectation is that sub-national governments will respond with new programmatic approaches to policy problems in their communities (Osborne, 1988; Volden, 1997; Gallup-Black, 1998). This framework complements the general claims that: (1) sub-national governments provide more effective policy outcomes because they are more closely tied to their respective constituencies, and (2) the transfer of power to a lower level of government allows public policy choices to be delegated to officials who are more in tune with local norms and values (Murray, 1984; Osborne, 1988; Eggers \& O'Leary, 1995; Kincaid, 1998) and thus better able to solve policy problems. Interestingly, these arguments may apply best to second-order devolution, which decentralizes policymaking authority to local officials.

Implicit in many, but not all, of these arguments is that devolution - and the resulting experimentation associated with devolution-leads to improved policy outcomes. As Kincaid (1998) suggests, devolution can promote more informed and responsive local governments. However, this assessment of devolution may be problematic. Moreover, "better" outcomes may result from devolution because policymakers are able to craft policies that are closer to the tastes of the median voter in their jurisdiction. Alternatively, if decentralization causes innovation, then it may also intensify inequalities among jurisdictions because some localities may be ill equipped and lack the personnel or policymaking capacities necessary to deal with the new authority (Kenyon \& Kincaid, 1991). Moreover, Rom (2005) questions the ability to recognize and act on successful outcomes. Or, as others argue, devolution may result in a "race to the bottom." Stated differently, there may be little incentive for localities to offer services if doing so will encourage more individuals to reap the benefits provided by certain sub-national governments (Landy \& Teles, 2001; Peterson \& Rom, 1990, 1989; Peterson, 1981, 1995). 
Lieberman and Shaw (2000) suggest a second framework-one that predicts little to no policy innovation or learning because of devolution. This approach contends that national pressures trump the efforts of sub-national governments to innovate. For instance, Peterson $(1981,1995)$ suggests that states do not have the necessary resources to enact effective redistributive policies. Nevertheless, national politicians may pursue an agenda of policy devolution because it allows them to deflect blame for failing and unresponsive government programs (Gilens 1999; Bobo \& Smith, 1994). The central finding of Lieberman and Shaw's (2000, 235) study of welfare waivers is that the elimination of national controls caused "states to follow national rather than local imperatives in setting welfare policy."

\section{Policy Learning}

Despite being one of the primary rationales underlying policy devolution, few scholars explicitly test the actual connection between devolution, policy experimentation, and learning in sub-national governments. Perhaps this is so because significant controversy exists with respect to what "learning" is and how it actually takes place. In fact, the policy learning literature has been called a "conceptual minefield" (Levy, 1994: 279). For example, learning is characterized as policy oriented (Sabatier, 1987, 1988), political (Heclo, 1974), instrumental (May, 1992), and even causal (Levy, 1994). Busenberg (2001, 173) provides one definition of policy learning as a "process in which individuals apply new information and ideas to policy decisions." Similarly, the concept of "organizational learning" has been somewhat elastic, with scholars again applying the concept quite differently (Cohen \& Sproull 1995). Likewise, learning has been characterized as both driven by the replication of behaviors within a government and by learning across governments (Berry \& Berry 1990). One common element to the scholarship on policy learning, as Lupia and McCubbins (1994; see also Volden, 2006; Carpenter, 2002) stress, is that it requires the updating of previously held beliefs over time.

\section{Testing a Primary Rationale for Devolution}

Proponents of devolution often claim that it creates an environment in which local officials have both the opportunity and the incentive to learn from policy experimentation in order to advance towards better policies and results. However, the linkages underlying this argument in support of devolution and have not been explicitly specified or empirically assessed. When referring to the devolution of welfare policy, Volden $(1997,67)$ furthers this sometimes implicit rationale for devolution by suggesting the importance of internal policy innovation. He writes: "states and localities are 'closer to the people' and thus have better access to information about the needs of recipients and about community employment opportunities. This information...will provide the best possible environment for successful experimentation in welfare policy." 
We move our understanding of political science, public policy, and public administration forward by explicitly stating and testing one of the primary theoretical justifications for devolution. The relationship is as follows: devolution $\rightarrow$ policy experimentation $\rightarrow$ internal learning $\rightarrow$ improved outcomes. As Ferejohn and Weingast $(1997,157)$ highlight, recent "interest in federalism raises concerns...as policymakers and researchers have begun to ask whether the devolution of some programs to the states might result in better policy." It is due to these concerns, compounded by a lack of understanding regarding the causal mechanisms underlying devolution, that we posit and evaluate the following hypothesis: Devolution provides an opportunity for sub-national officials to "learn" to replicate programming that yields successful outcomes via their internal policy experimentation.

This hypothesis suggests that one of the main mechanisms driving change after devolution is the internal policy innovations initiated by sub-national officials. It is this argument that we directly engage and test. ${ }^{2}$ Stated differently, the hypothesis contends that the flexibility afforded by devolution allows local officials to make critical adjustments to programming, and then, to learn over time to replicate programming that works. We define policy innovations as any changes to existing programming or spending on programming at the sub-national level. To define "policy learning," we rely on May's understanding. May (1992: 336) states that one of the most basic forms of learning is associated with the "viability of policy interventions or implementation designs." May's definition provides traction for scholars as he suggests that this type of learning can be identified and tracked by observing the decisions made by government officials over time.

\section{The North Carolina Case}

We evaluate the hypothesis discussed above by turning to the politics surrounding the devolution of some welfare-related policymaking authority in the 1990s. As is well documented, in 1996 the TANF (Temporary Assistance to Needy Families) legislation replaced AFDC (Aid to Families with Dependent Children) with new directives and program requirements focused on putting recipients to work and limiting their time on the welfare rolls. When the United States Congress passed this welfare reform legislation, it transferred select policymaking authority to the states in the form of block grants. While some scholars note that this transfer of policymaking authority generated a conflicting set of goals, including protecting families from poverty and controlling costs (Gueron, 1998; Meyers, Riccucci \& Lurie, 2001; Cancian \& Meyer, 2004), the primary goal they associate with TANF is reducing the welfare caseload via an emphasis on work (Cancian \& Meyer 2004; Loeb \& Corcoran, 2001; Danziger et al., 2002). 
For the majority of American states, the devolution of policymaking authority from the national government ends with the states having full responsibility for administering TANF (Winston, 2002; Gainsborough, 2003). For a sub-group of states, however, local governments play an important role in administering welfare reform, and often, counties emerge as the main recipients of devolved welfare policymaking authority. In fact, some scholars suggest that a grave omission in the debates surrounding welfare reform is "[t]he consequences of administering welfare-to-work programs through county-level agencies" (Hughes, 1998: 562; see also Gainsborough, 2003).

In this article, we investigate the consequences of devolution within one such state-North Carolina. In 1997, the North Carolina General Assembly passed legislation that shifted some welfare policymaking responsibilities to the counties. The devolution of authority occurred primarily through the use of block grants to each of the 100 North Carolina counties. The county governments were given considerable discretion with regards to the spending of these grants, provided that they made progress on several state-established goals for welfare reform. The state goals roughly correspond with the directives established in the federal TANF legislation and include a focus on reducing the welfare caseload via the achievement of employment by former welfare recipients, as illustrated by the program's name: Work First. In fact, according to our case study and survey research, it was considered a critical measure of welfare policy "success" at both the state and local level in North Carolina. Additionally, North Carolina county officials were evaluated on their ability to measurably decrease the welfare rolls (Barth, 2000; Scavo, 2000; DeHoog \& Mattiello, 2000; Rassel \& Etringer 2000).

North Carolina provides a strong case from which to generate and generalize conclusions concerning the ramifications of policy innovation for sub-national governments. As Barrilleaux and Miller (1988) note, the capacity of state bureaucracies to understand and react to complex problems can affect policy implementation. North Carolina has a strong system of county governance that has been characterized as "state-supervised, county-administered" (Cooke \& Haithcock, 2002: 32). Historically, North Carolina county governments played a vital role in administering social service programs. Consequently, the counties have high levels of administrative capacity and significant policymaking experience. This context provided a solid foundation for county officials as they attempted to meet the challenges created by the 1996 national and 1997 state devolution of welfare-related policy authority. Furthermore, North Carolina has substantial variation in terms of political ideology, population, racial composition, welfare clientele, and economic well-being. 


\section{Data, Methods, and Results}

We use the policy choices made by North Carolina county officials to evaluate the hypothesis linking devolution with policy learning and improved outcomes. We begin by first establishing that new welfare-related policy flexibility and authority was transmitted to local officials in the late 1990s. We then test the hypothesis in two steps. First, we determine the spending patterns by county officials that yielded successful policy outcomes over a three-year period (1999 to 2001). More specifically, we use cross-sectional time series regression analyses to investigate the relationship between programmatic spending decisions in individual counties and improved results with respect to welfare caseload reduction. Second, based on the findings regarding successful programming from the first analyses, we evaluate whether county officials demonstrated learning by comparing successful budgetary decisions from 1999 to 2001 with subsequent year-to-year budgetary decisions. When we observe counties repeating successful spending patterns in later years, we conclude that the county officials learned to spend funds on programming that helps them achieve their desired results.

\section{Evidence of Policy Devolution}

We first establish that devolution shifted new power to government officials in North Carolina. To do so, we use two data sources: (1) 23 case studies of select North Carolina counties, and (2) survey research administered in 2000 tapping the attitudes and assessments of sub-national officials about policy innovation and devolution. The case studies offer illustrative evidence that welfare reform accomplished the goal of shifting some policymaking authority to sub-national officials. ${ }^{4}$ Nearly all of the studies observed greater discretion in their respective counties as a result of devolution, and the vast majority also indicated that the 1997 state legislation gave counties additional fiscal flexibility. For example, in Robeson County, officials noted an increase in discretion and authority and also argued that even further autonomy would be desirable (Barbee, 2000). A Commissioner from Cabarrus County said that welfare reform served to "open the arena for innovation" (Rassel \& Etringer, 2000: 14). And as Scavo (2000: 11) concluded regarding Craven County: "Interviewees who were familiar with the internal operations of Work First (the DSS Director and the DSS Board Chair) mentioned that they felt a greater sense of flexibility and autonomy in the program now than they had before Work First was implemented. The County Manager said that the county had more autonomy in welfare policy now than it had five years ago."

Survey data provide additional evidence of devolution. ${ }^{5}$ The survey gathered the perceptions of five county actors (with the following response rates) in each of the 100 North Carolina counties: County Commissioners (28\%), County Managers (65\%), Chairs of Department of Social Services (DSS) Boards (65\%), DSS 
Directors (67\%), and Work First Administrators (70\%). ${ }^{6}$ County officials were specifically asked to assess the level of policymaking authority present in their county before and after the 1997 state welfare reform legislation. The survey evidence identifies a statistically significant increase in authority by 2000 . We conclude from both the case studies and these survey results that the federal and state block grants shifted notable new policymaking authority to the 100 North Carolina counties. This conclusion is also supported by Gainsborough (2003, 607) research, which finds that North Carolina as one of eight states where the state-level welfare reform legislation devolved significant powers to county governments.

\section{Step One: Establishing the Actions That Yield Success}

We now turn our attention to identifying the actions that yielded success in North Carolina counties from 1999 to 2001. As we detail below, we ran hundreds of separate analyses using these three years of data to identify programming that worked (i.e., improved outcomes) in each county. Our particular programmatic foci were childcare and transportation spending. Later in the article, we use the findings from these analyses to judge whether, in subsequent years, counties learned to select policies that improved outcomes.

Some may challenge our use of quantitative analyses to identify what county officials should have done in their districts, thereby suggesting that county officials do not have this level of knowledge regarding their policy environments. Yet, the causal argument we are testing is predicated on the fact that sub-national officials have the necessary, localized knowledge and information to address their community's problems. Thus, this line of reasoning presumes that sub-national officials are able to sort through a multitude of competing explanations. While these officials, we submit, do not use statistical analyses to make their judgments, our research strategy mimics this process and provides us-as third party researchers - an analogous mechanism for judging which factors positively affected welfare-related outcomes in sub-national communities.

\section{Data and Variables}

Our measure of welfare success was the number of adults leaving the rolls in a particular county and year (Number exited). This dependent variable corresponded with a key goal at both the national and sub-national levels: the reduction of the welfare caseload. Moreover, county officials in North Carolina were judged by the state regarding their performance on this measure of success. As DeHoog and Mattiello (2000: 13) summarized in one case study, "The primary goal of Forsyth County's Work First program was to promote self-sufficiency among the client population, through a number of incentives and staff assistance in job placements and support services." The exit data for the dependent variable were collected 
from the North Carolina Department of Health and Human Services. To account for discrepancies in terms of county caseload and county population differences, we standardized the Number exited variable by the number of individuals on the caseload in a county in that particular year.

We grouped the independent variables in our analyses into five broad categories(1) fiscal innovations, (2) county demographics, (3) caseload characteristics, (4) administrator attributes, and (5) interaction effects. First and most importantly, the fiscal innovations were included to establish which type of spending resulted in more successful outcomes. The specific foci were childcare and transportation programming. The next three variable groupings were included as controls for the economy, caseload characteristics, and the quality and experience of county administration. The final category tapped the importance of the fiscal innovations in particular counties-via the inclusion of an interaction between a county dummy variable and the specific programmatic spending area of interest. We detail these variables more fully below.

Fiscal Innovations Variables. The primary explanatory variables in the models measured welfare expenditures related to childcare, transportation, and other welfare services in each of the 100 North Carolina counties. ${ }^{7}$ We created the following three variables: Spending on childcare, Spending on transportation, and Total other services spending. Each of these variables was standardized by the number of individuals on the welfare caseload in a county for a particular year. ${ }^{8}$ While all three of these figures included dollars from federal, state, and county sources, county officials possessed new authority after the 1997 legislation to decide how these block grant funds were spent in their jurisdictions. The Total other services spending measure, which was devoid of spending on childcare and transportation, was included as a control variable in all of the analyses and includes spending on job training. We use 2004 dollars to standardize all monetary figures. Also, the 1999 expenditure data represents spending that took place during fiscal year 1998 to 1999,2000 represents fiscal year 1999 to 2000, and so on.

We relied on the budgetary decisions of sub-national officials to track county policy choices after devolution for two main reasons. First, budgetary choices constitute some of the most pressing programmatic and policy-related decisions made by sub-national officials. Budgetary decisions are controversial policy issues that can both constrain and promote a government's activities (Kindgon, 1995). Expenditures are often at the center of electoral debates and, more generally, are important for defining differences between liberals and conservatives (Jacoby, 1994). Moreover, sufficient funding is a prerequisite and critical driving force behind the formation and implementation of meaningful policy (Garand \& Hendrick, 1991; Raimondo, 1996). Second, by concentrating on spending shifts within well-defined programmatic categories, we can compare 
across the 100 counties. There is notable consistency with respect to the reporting requirements for welfare expenditures, with all counties required to select from identical state-established reporting codes and budgetary categories. ${ }^{9}$ Across counties and years (1999-2001), the standardized ranges for each of these variables were: (1) childcare expenditures, $\$ 0$ to $\$ 657$, and (2) transportation, $\$ 0$ to $\$ 593$.

We focused on childcare and transportation spending because these programmatic funding areas were considered crucial to furthering the goals of work and selfsufficiency among welfare recipients in the 1996 national and 1997 state legislation. Furthermore, these two funding areas stood out clearly within the 23 North Carolina county case studies. For example, Barth $(2000 \mathrm{a}, 9)$ suggests in his report on New Hanover County that "[ $\mathrm{t}]$ he concept is to spend money to remove any immediate obstacles, such as transportation and day care so that people can become self-sufficient and leave the welfare rolls." In Cabarrus County, the county's welfare implementation plan specifically cited the need to shift programming to meet childcare and transportation needs and to remove the "barriers to job placement for many Work First families" (Rassel \& Etringer, 2000: 3). Cooke and Alexander (2000: 12) describe how Caldwell County officials used their new flexibility to eliminate barriers to transportation for their Work First clients.

County Demographics. Several additional measures were included as control variables in all models. First, to control for the economic well-being of the county, we included the unemployment rate (Unemployment), collected from the North Carolina Employment Security Commission. Second, we included a control for county political party identification, operationalized as the proportion of voters in each county identifying as a Democrat (Percent Democratic voters). These figures were obtained from the North Carolina State Board of Elections. Third, we also collected data measuring the number of nonprofit agencies in each county, collected from the Urban Institute. This variable was also standardized by the number of individuals on the county caseload.

Caseload Characteristics. The third group of variables controlled for the characteristics of the welfare population in each county. This information was collected from the North Carolina Department of Health and Human Services. We included two variables to tap the racial composition of the rolls - the percent of African American individuals receiving benefits as well as the percent of Hispanics. Second, we included a control for family size, which measures the average number of cases each year with over five children. This variable is also standardized by the number of individuals on the welfare rolls. Finally, we included a variable $\left(\right.$ Earners $\left._{t-1}\right)$ to tap how the success of those individuals who left the rolls in the prior year influences current rate of exit. More specifically, this variable measures the number of leavers who earned some money in the year 
after their exit. We expect that when the leavers are more successful, the rate of exit for the current individuals on the rolls may also increase.

Administrator Attributes. We also account for several attributes of the county leadership. These variables were drawn from the previously described survey conducted in 2000 and thus do not vary over time. First, we included the average Age of administrators in each county who responded to the survey. Second, we included their average level of educational attainment. Finally, we included one attitudinal measure tapping the average perceived importance of securing workforce participation for recipients. The scale of responses ranged from 0 (none) to seven (high). Respondents were given a "Don't Know" option, which was excluded from the county averages.

Interaction Effects. The final category of variables included in our analyses tapped the importance of childcare spending or transportation spending in particular counties. As such, these were the key variables in the analyses. To create the variables, we first generated dummy variables for each of the 100 North Carolina counties. We then calculated 100 interaction effects by multiplying each county dummy variable by spending on childcare in that same county. [Similarly, we calculated 100 interaction effects by multiplying the county dummy variables by the spending on transportation in that county.] As detailed below, we included this set of variables one-by-one in a number of regression analyses to test the significance of spending in these priority areas on welfare outcomes in specific counties.

\section{Methods}

We turned to information from the 100 North Carolina counties at three points in time (1999 to 2001) to establish the programmatic spending patterns that yielded the greatest success in each county. We employed a Generalized Least Squares Error Components (GLS-E) modeling strategy (Maddala, 1971; Nerlove, 1971) to account for the pooled nature of this time series data. We also include year fixed effects (Sayrs, 1989). We estimated 200 separate models to isolate the effects of childcare and transportation spending. All of the explanatory variables were identical in each of the models with the exception of the interaction term between the county of interest and the relevant spending variable. We used the significance of the interaction effect to identify and isolate counties that benefited from shifts (be it increases or decreases) in spending on childcare or transportation programming. Among the counties with significant coefficients, we were then most interested in the sign of the combined effect between the county and the spending variable. For example, a positive, significant effect indicates that more spending on childcare was equated with greater exit from the rolls in a particular county. Thus, in subsequent years, this county should continue to spend more on childcare to improve outcomes. 


\section{Results}

Establishing what worked in each county is the first critical step toward testing the article's hypothesis. To do so, we estimated a base model, using Number exited as the dependent variable, to examine the overall effects of spending and the control variables in all North Carolina counties. Subsequently, we then estimated an additional 200 separate models, each of which included a particular county dummy variable as well as an interaction term between the county dummy and the spending area of interest. In Table 1, we present the results from the base model, as well as for two of the additional analyses by county. We use Dare and Lincoln counties to illustrate the patterns uncovered in the analyses, and focus on the interaction effects between the county of interest and childcare spending.

Table 1: Establishing the Actions Officials Should Have Taken for Childcare Programming, 1999-2001

\begin{tabular}{|c|c|c|c|}
\hline \multicolumn{4}{|c|}{ Dependent Variable: Number Exited } \\
\hline Fiscal Innovations & $\begin{array}{l}\text { Base } \\
\text { Model }\end{array}$ & $\begin{array}{c}\text { Dare County } \\
\text { (Significant } \\
\text { Interaction) }\end{array}$ & $\begin{array}{c}\text { Lincoln County } \\
\text { (Insignificant } \\
\text { Interaction) }\end{array}$ \\
\hline $\begin{array}{l}\text { Childcare Spending } \\
\text { Transportation } \\
\text { Spending } \\
\text { Total Other Services } \\
\text { Spending }\end{array}$ & $\begin{array}{c}0.00003 \\
(0.00004) \\
0.00002 \\
(0.00004) \\
-0.0002 \\
(0.0002)\end{array}$ & $\begin{array}{c}0.00008 \\
(0.00004) \\
-0.00002 \\
(0.00004) \\
-0.0002 \\
(0.00020)\end{array}$ & $\begin{array}{c}0.00003 \\
(0.00004) \\
0.00001 \\
(0.00004) \\
-0.0002 \\
(0.0002)\end{array}$ \\
\hline$\frac{\text { County }}{\text { Demographics }}$ & & & \\
\hline Unemployment & $\begin{array}{c}-0.0048 * * \\
(0.0014)\end{array}$ & $\begin{array}{c}-0.00554^{* *} \\
0.0013\end{array}$ & $\begin{array}{c}-0.0049 * * \\
(0.0014)\end{array}$ \\
\hline $\begin{array}{c}\text { Percent Democrat } \\
\text { Voters } \\
\text { Nonprofits }\end{array}$ & $\begin{array}{c}0.0136 * * \\
(0.0046) \\
0.0187 \\
(0.019)\end{array}$ & $\begin{array}{c}0.01325 * * \\
(0.0044) \\
0.01569 \\
(0.01817)\end{array}$ & $\begin{array}{c}0.0135 * * \\
(0.0046) \\
0.0173 \\
(0.0189)\end{array}$ \\
\hline$\frac{\text { Caseload }}{\text { Characteristics }}$ & & & \\
\hline $\begin{array}{c}\text { African American } \\
\text { Caseload }\end{array}$ & $\begin{array}{l}-0.0011 * * \\
(0.00013)\end{array}$ & $\begin{array}{c}-0.00115^{* *} \\
(0.0001)\end{array}$ & $\begin{array}{l}-0.0012 * * \\
(0.00013)\end{array}$ \\
\hline $\begin{array}{c}\text { Hispanic Caseload } \\
\text { Family Size }\end{array}$ & $\begin{array}{c}-0.0022 * * \\
(0.0011) \\
-1.7788 * * \\
(0.8548)\end{array}$ & $\begin{array}{c}-0.00318^{* *} \\
(0.0011) \\
-1.4327 * * \\
(0.8290)\end{array}$ & $\begin{array}{c}-0.0022 * * \\
(0.0011) \\
-1.770 * * \\
(0.8534)\end{array}$ \\
\hline
\end{tabular}


S. Webb Yackee \& C. Kelleher Palus: Learning from Experience? Second-Order Policy

Devolution and Government Responsiveness

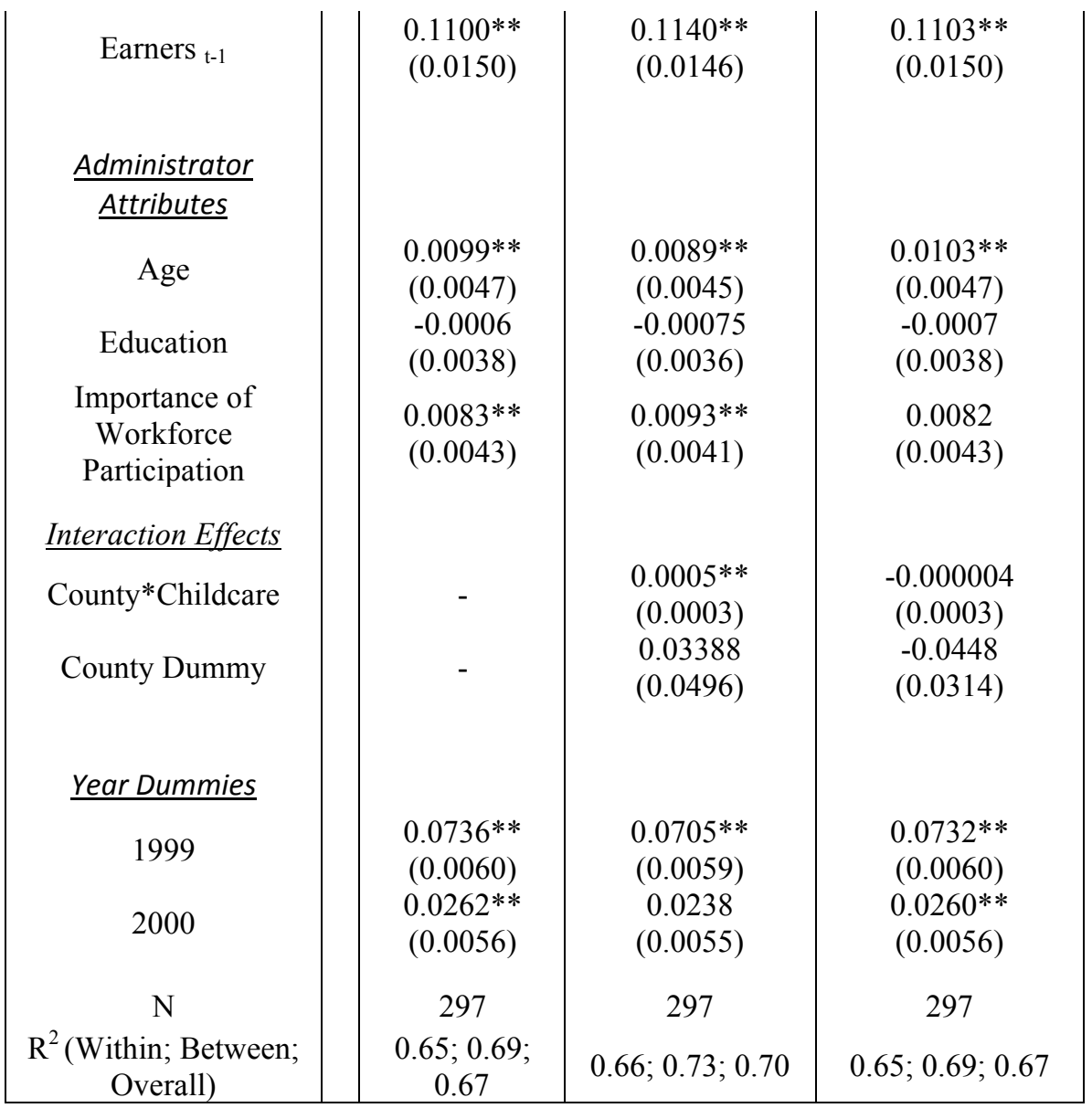

Notes: Models estimated using a generalized least squares error components (GLS-E) modeling strategy.

$* * \mathrm{p}<0.05$ (one-tailed test).

In the first column of Table 1 (the base model), the control variables behave largely as anticipated. For instance, as unemployment increases in a county, exit from the welfare rolls is less likely. Additionally, when African Americans or Hispanics occupy a larger proportion of the rolls, exit is less common. ${ }^{10}$ And, as the family size grows, the number of leavers similarly declines. We also observe some significant effects of administrator attitudes and characteristics. For example, when, on average, administrators point to the importance of workforce participation as a goal of welfare policy, exit is more likely. The spending indicators are not significant at traditional levels, but both run in a positive direction. Finally, while we had no specific expectations for the partisanship 
variable, it appears that counties with a greater percentage of Democratic voters had a greater rate of exit.

With the findings for the base model established, we then added two variables to the base model - a county dummy as well as the county dummy and spending interaction term. The second column in Table 1 provides for the results for Dare County. We conclude that in this county, childcare spending from 1999 to 2001 significantly improved welfare-related outcomes. In fact, this model specification indicates that when officials spent more on childcare programming - and presumably, less on other types of programming-welfare outcomes were improved. The coefficient for the interaction term is significant and positive, and when this interaction term is combined with the coefficient for the childcare spending variable, the full effect is 0.00058 . The t-statistic for this combined effect is 2.061 , and the effect is statistically significant. These results imply that between 1999 and 2001, greater spending on childcare programming in Dare County was linked with more desirable welfare outcomes. According to one of the central claims of devolution, county officials should have been aware of this trend and then, in subsequent years, acted upon it. If this reasoning is correct, then Dare County officials, who are "closer to the people," should have picked up on these trends and learned from their experimentation to spend more on childcare programming in future years. In our second set of analyses, we explore whether this actually proved true.

In Lincoln County, we draw a different conclusion from the results presented in the third column of Table 1 . Here, we see a county where spending on childcare programming did not significantly affect the number of people leaving the county's welfare rolls. The t-statistic for the combined effect of the interaction term and childcare spending variable indicates an insignificant relationship. Thus, we infer that there was no clear signal sent to local officials with respect to the connection between spending on childcare and exit from the rolls. Therefore, we should not expect these officials to have learned from their experimentation with childcare programming in this county.

In Table 2, we present the aggregate-level results from 200 analyses-100 of which focused on childcare spending in each of the North Carolina counties and 100 on transportation expenditures. Three major points stand out in this table. First, 32 counties did not shift their spending on childcare between the years of 1999 and 2001, and thus, in one-third of the North Carolina counties, devolution does not appear to spur experimentation within this key welfare programming area. However, with respect to transportation programming, all of the counties experimented - at least to some degree. Second, as illustrated by the insignificant combined effects in the regression analyses, childcare spending in 33 counties did not significantly influence welfare outcomes, while in 69 counties, transportation spending had no discernable effect. 


\section{Table 2: Aggregate Totals for Significant Links between Experimentation and Outcomes}

\begin{tabular}{|ccc|}
\hline & Childcare & Transportation \\
\cline { 2 - 3 } No experimentation & 32 & 0 \\
$\begin{array}{c}\text { Experimentation - } \\
\text { Insignificant effect on } \\
\text { outcomes }\end{array}$ & 33 & 69 \\
Experimentation - & 11 & 13 \\
$\begin{array}{c}\text { Significant effect on } \\
\text { outcomes* }\end{array}$ & & \\
Experimentation - \\
Significant effect on \\
outcomes $\checkmark$
\end{tabular}

Notes: The total observations equal 99 because Hyde County drops from all analyses due to missing survey data. ${ }^{*} \mathrm{p}<0.10 ; \checkmark 0.10 \leq \mathrm{p}<0.25$ (one-tailed tests).

Third, and most importantly, spending on childcare or transportation significantly affects exit from the rolls in several North Carolina counties from 1999 to 2001. We rely on two standards to determine statistical significance. First, under a criterion of $\mathrm{p}<0.10$ (one-tailed tests), we observe 11 counties in which childcare spending influenced exit, and 13 counties in which there was a significant effect for transportation. We then relax the criterion for significance to $\mathrm{p}<0.25$ (onetailed tests), and an additional 23 counties for childcare, and 17 counties for transportation emerge as possible learners. By expanding the threshold for statistical significance beyond standard bounds, we extend the possibility of learning to a larger subset of counties. We cast this wide net to ensure that we examine all counties that may have learned in the subsequent analyses. ${ }^{11}$

We observe a significant effect between spending and exit in a total of 34 counties due to childcare expenditures, and 30 counties for transportation using both sets of statistical criteria. These aggregate totals fit well with the existing literature citing and debating multiple explanations for changes in welfare caseloads. ${ }^{12}$ Consequently, it is within this subset of North Carolina counties - the counties where childcare or transportation spending mattered to the key outcome of reducing welfare caseload-where we can reasonably expect policy learning to 
take place. With this information in hand, we now look for evidence of learning in these counties in the second step of our analyses.

\section{Step Two: Devolution and Evidence of Policy Learning}

\section{Data and Methods}

Does devolution encourage policy learning by sub-national officials? Do they replicate programming that yields measurable improvements for welfare recipients? Our analysis relied on May's (1992) observation that learning can be tracked by focusing on over time variability in policy decisions. We operationalized this strategy by first isolating the counties where a significant relationship existed between spending on childcare or transportation and exit from the welfare rolls from 1999 to 2001. Second, we noted the sign for the effect of the interaction term for these counties. This information suggested whether a county's decision to spend more or less on childcare or transportation influenced the rate of exit from 1999 to 2001 . Third, we turned to the subsequent fiscal decisions made by county officials regarding childcare and transportation spending. Here, we investigate whether the year-to-year changes increased or decreased from 2001 to 2002 and then from 2002 to 2003. Finally, we compared the results to the Step One analyses. We concluded that learning occurred when the decisions of county officials with respect to spending in these later years matched the earlier patterns associated with welfare-related policymaking success. ${ }^{13}$

Before moving forward with our analyses, we compared the characteristics of the caseloads in 1999, 2000, and 2001 with those on the rolls in 2002 and 2003. Essentially, our goal was to ensure that the clients being served in the latter years did not differ systematically from earlier cohorts. In other words, we want to make sure that we are comparing "apples to apples" and not "apples to oranges." From 1999 through 2001, the caseload in North Carolina was approximately 51\% African American and 2.5\% Hispanic. In 2002 and 2003, the demographics of the caseload were similar although not identical - approximately $50 \%$ black and $4 \%$ Hispanic. In the earlier years, the average number of child-only cases in each county was nearly 252; in 2002-2003, it dropped slightly to 234 . With respect to family size, in the earlier years, nearly nine cases (on average) in North Carolina counties had five or more children as compared to approximately five cases on average in 2002-2003. ${ }^{14}$ Thus, we conclude that the cohorts for each time period were substantially similar, and given these sensitivity analyses, it appears reasonable to expect some continuity in the calculations and decisions of administrators across these time periods with regards to the administrative allocation of welfare-related funds. 


\section{Results}

Tables 3 and 4 highlight the results for counties considered learners, partial learners, or non-learners. Distinctions are also made between the significance levels from the Step One analyses $(\mathrm{p}<0.10$ and $\mathrm{p}<0.25)$. We draw a number of conclusions from these tables. First, for childcare, we observe that four counties learned to use the fiscal flexibility afforded by devolution by replicating successful programming over time. The Step Two analyses demonstrate that these four counties increased their spending from 2001 to 2002 and then again from 2002 to 2003 in this programmatic area. In other words, officials in these four counties made year-to-year adjustments that demonstrate policy learning. Notably, there were also 13 other counties that we characterized as "partial learners." We considered them open to the potential of learning because they repeated the behavior associated with improved outcomes in one of the two study years (either changes from 2001 to 2002 or 2002 to 2003). Thus, of the 34 counties where childcare spending was equated with success, four counties, or about 12 percent, displayed unambiguous evidence in support of the hypothesis. Seventeen counties provided no evidence of learning, and we conclude that they did not recognize successful fiscal patterns and replicate them.

Table 3: Learning on Childcare in North Carolina Counties, 2001-2003.

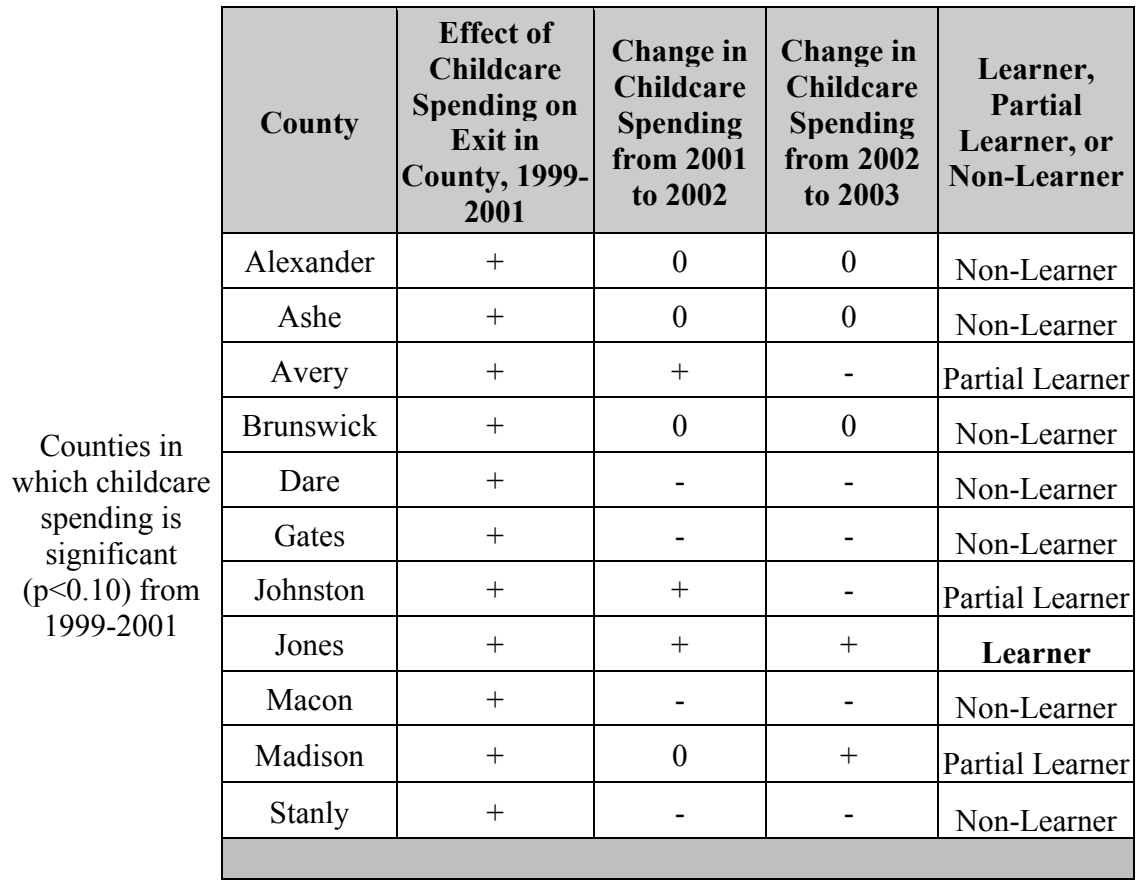




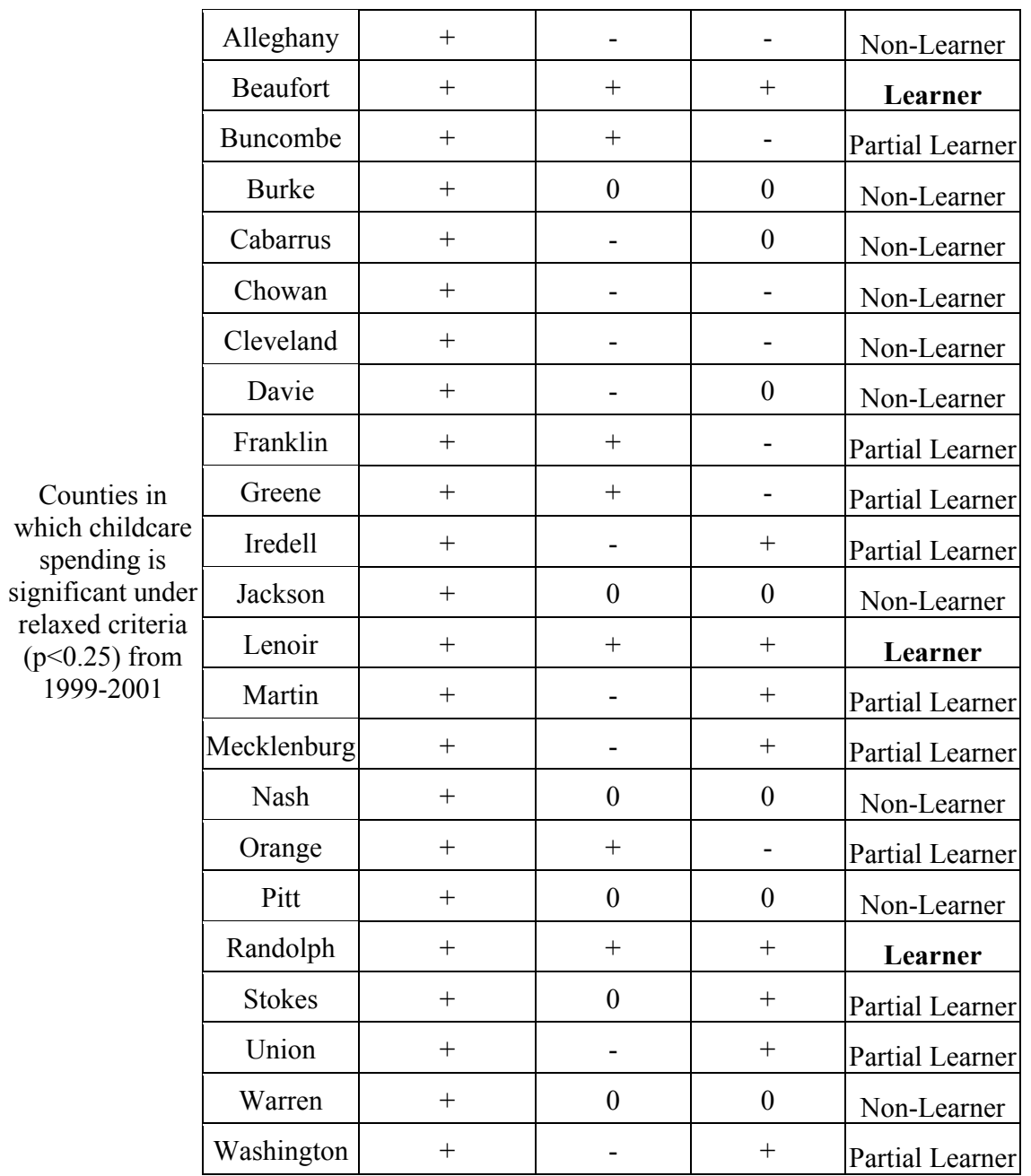

Aggregate Totals: 4 Learners, 13 Partial Learners, 17 Non-Learners 
Table 4: Learning on Transportation in North Carolina Counties, 20012003

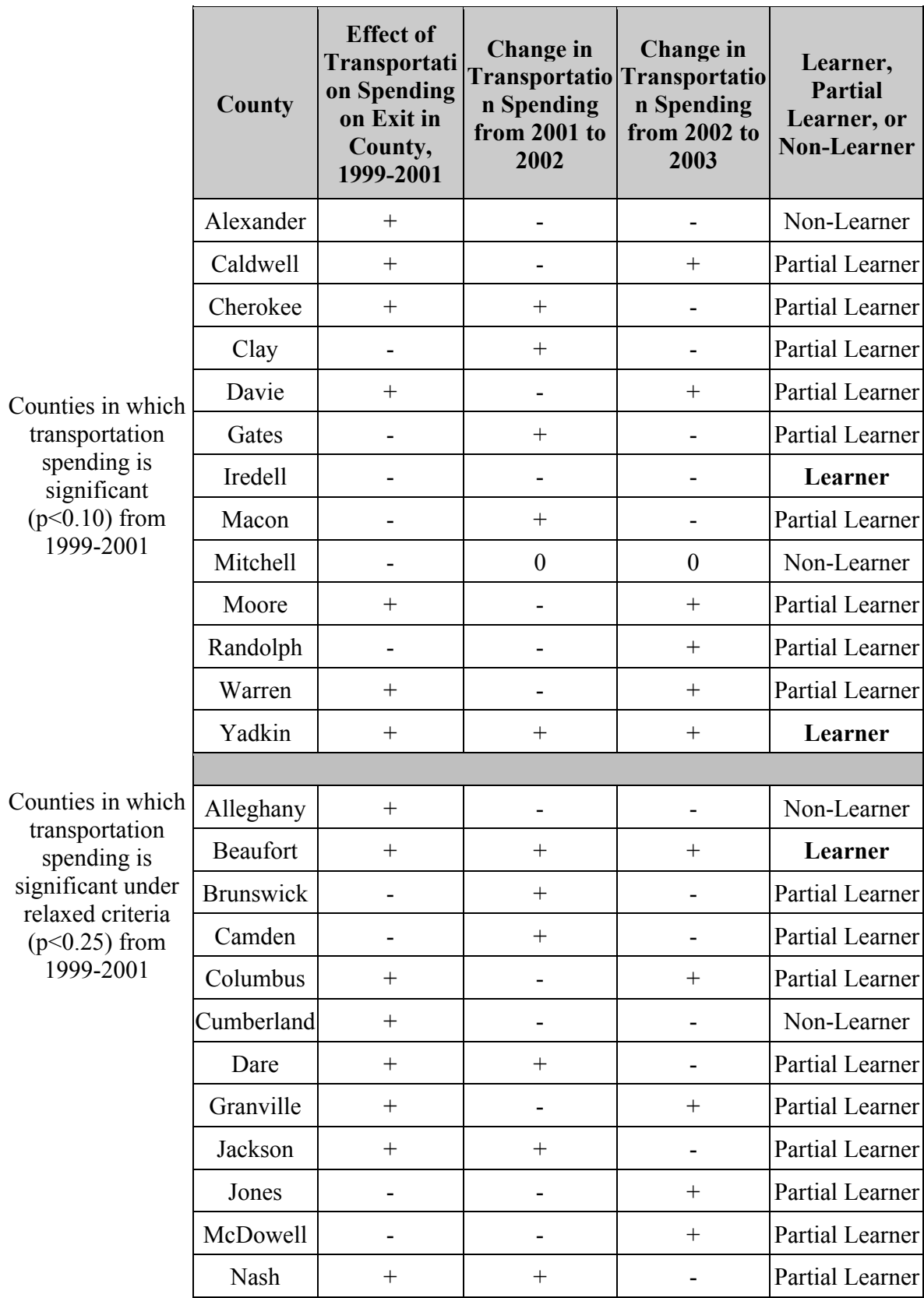




\begin{tabular}{|c|c|c|c|c|} 
Stokes & - & - & + & Partial Learner \\
\hline Tyrrell & + & - & + & Partial Learner \\
\hline Union & + & + & + & Learner \\
\hline Vance & + & - & - & Non-Learner \\
\hline Washington & + & - & - & Non-Learner \\
\hline
\end{tabular}

Aggregate Totals: 4 Learners, 20 Partial Learners, 6 Non-Learners

Similarly, while a significant relationship existed between transportation spending and improved welfare outcomes for 30 counties, only four counties display solid evidence of policy learning. Of these "learners," three of the counties - Yadkin, Beaufort, and Union - should have allocated more money to transportation programming and did just that. In Iredell County, however, less spending yielded greater success, and in later years, Iredell demonstrated policy learning by assigning fewer government dollars to transportation services. Stated differently, overall about 13 percent of the 30 counties where officials could (and should) have learned, provided clear evidence of learning. We classify 20 counties as "partial learners" because they, at least once, replicated successful spending decisions. In six counties, no evidence of learning was evident.

In short, we find only limited evidence of policy learning after devolution in county spending patterns on childcare and transportation programming. Moreover, we should note that while the definition of policy "learning" underlying much of the devolution argument focuses on the internal policy choices by government actors, sensitivity analyses of these data display little evidence of learning from neighboring counties either. ${ }^{15}$ In sum, our findings are in contrast to the empirical expectations of the article's hypothesis. Thus, despite being "closer to the people," local leaders in North Carolina had a difficult time identifying and making decisions that lead to reductions in welfare caseloads in their communities. Instead, these results appear to suggest support for Mossberger and Hale's (2002: 418-419) conclusion that new information on policy experimentation provides "no guarantees for policy learning because ultimately, learning depends on the way in which available information is used."

These surprising results, however, must be viewed within the context of the study's research design and must only be seen as exploratory in nature. For instance, our focus on one state and one policy issue allowed us to gather substantial data and information in the form of case studies, survey research, and administrative and fiscal records. In fact, these data took over six years to collect, clean, and analyze. Future work must now expand the analysis to other policy areas and governmental units to assess further the generalizability of the findings. Moreover, in this study, we studied the primary goal identified within North Carolina case studies (Barth, 2000; Scavo, 2000; DeHoog \& Mattiello, 2000; Rassel and Etringer 2000) and our survey research, which is moving people off the 
welfare caseloads. However, we acknowledge that other goals may also be associated with welfare reform, such as reducing spending across all programming and other non-work related goals. Future works must incorporate and reconcile the possibility of additional goals. Yet, despite these calls for future research, the article's empirical analyses remain noteworthy: these findings cast doubt on a key line of political reasoning frequently used to advance policy devolution across localities, states, and counties.

\section{Conclusions}

The primary contribution of this article is theoretical - essentially, in its specification of often-implicit framework used to promote policy devolution. In fact, a number of scholars and politicians promote the use of devolution without specifically examining the consequences of devolution for sub-national governments. As Conlan (1998: 11) notes, decentralization has been viewed as a "plausible policy response" that appeals to "natural partisan predispositions." Yet, despite the rhetoric and use of devolution to transfer some policymaking authority "closer to the people," the existing literature often fails to specify the theoretical mechanisms at play, and there are, consequently, few empirical examinations of the causal arguments underlying decentralization. In this article, we begin to address this gap in our understanding by unpacking one of the primary theoretical arguments in support of devolution, which connects devolution, innovation, and learning to more successful policy outcomes.

Our findings can be summarized as follows: First, devolution led to experimentation in the areas of childcare and transportation, albeit in varying amounts, in the majority of North Carolina counties after the 1996 national and 1997 state welfare reform legislation. Second, when learning is defined the internal replication of successful policy innovations, there appears to be little support for the hypothesis that the flexibility afforded by devolution leads to policy learning on the key outcome measure of caseload reduction. In fact, subnational officials in only four counties learned to shift their transportation dollars to best suit the needs of their counties, and four counties learned with regards to childcare programming. Stated differently, our findings suggest that the link between programmatic spending decisions and welfare caseload reduction was not recognized by the majority of sub-national officials. Thus, this exploratory empirical investigation uncovers little preliminary evidence in support of an oftenimplicit theory of policy devolution. However, additional research is needed to confirm and expand upon the descriptive trends found in these analyses. It is our hope that this article spurs just this type of research.

These results are noteworthy given that North Carolina county leaders appeared to be particularly well suited to respond to the opportunities offered by policy decentralization. This state and policy area served as a "crucial case" (Eckstein, 


\section{LEX LOCALIS - JOURNAL OF LOCAL SELF GOVERNMENT

1975) because it was a prime setting for uncovering evidence of a connection between devolved policymaking authority, learning, and improved policy outcomes. Yet, even under these circumstances, the article's findings point to the complicated relationship between organizational capacity and learning capabilities after policy devolution. As Blank and Haskins (2001: 37) conclude with regards to devolved welfare policy authority, "[I]mplementation demands not only rule formulation and institutional engineering but also a capacity for governance, a capacity to alter program elements in light of new information, circumstances, and experiences."

We close by suggesting that our conclusions with regards to policy devolution are certainly not all negative. One of the main tenets of modern federalism is the ability of sub-national governments to encourage innovation and successful policy ideas (Conlan, 1998; Kincaid, 1998; Walker, 2000), and this rationale is implicit to many, but not all, studies of devolution and many studies of policy adoption. On this point, our study indicates that devolution spurred policy experimentation in the vast majority of North Carolina counties with regards to childcare and transportation programming. While this experimentation did not necessarily translate into clear "lessons learned" in all of the counties, our results demonstrate that devolution spurred policy change. This change-in and of itself-may hold considerable normative value within a federalist system of governance.

\section{Notes}

${ }^{1}$ We should note that this line of reasoning argument is certainly not only pathway leading to "better" outcomes in sub-national jurisdictions. Instead, we present the argument as a frequently referenced rationale for devolution presented both in academia and in more mainstream political debates, which hitherto fore has escaped close scrutiny. We aim to narrow this gap in our knowledge.

2 Policy learning may occur via other mechanisms, such as learning from neighboring or likeminded political jurisdictions (Berry and Berry 1990; Boehmke and Witmer 2004; Volden 2006). Yet, from our reading, the "closer to the people" argument underlying our analysis rests much more firmly on the internal experimentation and innovation provided by devolution than on the geographic focus of some studies of policy diffusion. Nevertheless, we do provide sensitivity results later in the paper that explores this alternate pathway for learning.

3 May $(1992,336)$ refers to this type of policy learning as "instrumental learning."

4 The reports were written in 2000 by 12 faculty associates at 11 University of North Carolina institutions across the state. To determine whether the trends and patterns apparent within these reports might be generalized to the rest of the state, we examined the representative nature of the 23 case study counties as compared to the entire state of North Carolina. We analyzed the general demographic, economic, and political characteristics of these two groups. The largest difference occurred in the population category. This, however, is not surprising because the case studies included some of the most populous counties in the state (including Mecklenburg, Durham, Wake, Forsyth, and Guilford). The case study counties also appeared slightly more economically advantaged than the state as a whole with the unemployment rate 
approximately 20 percent below the state average. The average declines in exit from the rolls were quite similar.

5 The reliance on perceptions (or attitudes) as an indicator of intergovernmental relations is utilized by numerous scholars of American federalism (e.g., Wright 1988; Rosenthal and Hoefler 1989). And there is some scholarly consensus that an important dimension of intergovernmental reality is reflected in how intergovernmental actors perceive their world and how they respond within a framework of changing national-state (or state-county) relations.

${ }^{6}$ A total of 146 of the 525 County Commissioners responded. For each of the other county officials, 100 individuals were contacted. We performed a series of random phone surveys of the County Commissioner non-respondents. Results of this sensitivity analysis indicate that the County Commissioner non-respondents were not systematically different from the respondents, and therefore we are confident in the sample of County Commissioners.

7 This information came from the North Carolina Department of Health and Human Services on the WC373 forms. These forms detailed counties' expenditures on welfare-related administration and services. We worked with the North Carolina Comptroller's Office, as well as a variety of county and local officials, to verify and to validate the figures.

${ }^{8}$ The correlation between these variables was 0.30 and below for 1999 through 2001 .

${ }^{9}$ Notable consistencies also exist with respect to eligibility requirements for welfare across all counties.

10 This result is in line with the importance that scholars have placed on the racial composition of welfare caseloads (Soss et al. 2001; Fellowes and Rowe 2004; Fording, Schram, and Soss 2005).

11 Thus, we are primarily concerned with minimizing type two errors. We are aware that this has ramifications for our findings, and thus, we exercise caution in the later presentation of our findings to keep levels of statistical significance distinct.

12 In fact, in our base model and all additional models, we control for (and observe the significance of) several of these competing explanations.

13 From 2001 to 2003, many states experienced significant fiscal distress, and some local governments in North Carolina experienced limitations in the availability of revenues in certain policy areas. However, with respect to welfare spending, the majority of funds originated with the federal government. Thus, North Carolina counties' welfare programs did not decrease like some other public programs during fiscally troubled years.

14 Among these four comparisons, statistically significant differences existed for the percent Hispanic and the average family size. Thus, in the latter years, the North Carolina average county caseload included a slightly larger Hispanic population but there were fewer large families in the caseload. These significant differences are not particularly surprising considering the large sample sizes for each time period (300 and 200, respectively).

15 In these sensitivity analyses, we mapped the counties characterized as "learners" and "partial learners" to assess the possibility of geographic diffusion of policy ideas. While this type of diffusion does not motivate the argument in support of devolution investigated in this article, the policy diffusion literature suggests that it is a viable causal mechanism and certainly worthy of examination (e.g., Berry and Berry 1990). In these data, we see little support for this alternate theory. For example, very few of the neighboring counties directly surrounding child care learners were also similarly classified as either learners or partial learners. Of the four child care learners, the greatest percentages of "neighboring learners" (either full or partial) were observed for Lenoir and Beaufort Counties (33\%). In other words, one-third of their surrounding counties behaved in a manner consistent with successful spending of child care dollars on exit from the welfare rolls. Among the 13 "partial learners" with respect to child care spending, again we observe no regional or geographic trends; learners are not clustered near other learners. For transportation, a largely similar story is observed. Among the four 


\section{LEX LOCALIS - JOURNAL OF LOCAL SELF GOVERNMENT S. Webb Yackee \& C. Kelleher Palus: Learning from Experience? Second-Order Policy Devolution and Government Responsiveness}

"learners," only Yadkin County is surrounded by a somewhat substantial percentage of learning or partially learning counties at $50 \%$. For the twenty partial learners for transportation spending, in three counties isolated in the southwest corner of the state (Cherokee, Clay, and Macon), there may be a slight geographic trend. However, for the remaining seventeen counties, no trend is evident.

\section{References}

Barbee, D. (2000) In-Depth Report: Robeson, North Carolina, Retrieved October 15, 2001 from the Tracking County Responses to Welfare Reform Web site.

Barrilleaux, C. J. \& Miller, M. E. (1988) The Political Economy of State Medicaid Policy, American Political Science Review, 82 (4), pp. 1089-1107.

Barth, T. J. (2000) In-Depth Report: New Hanover, North Carolina, Retrieved October 15, 2001, from the Tracking County Responses to Welfare Reform Web site.

Berry, F. S. \& Berry, W. D. (1990) State Lottery Adoptions as Policy Innovations: An Event History Analysis, American Political Science Review, 84 (2), pp. 395-415.

Bobo, L. \& Smith, R. A. (1994) Antipoverty Policy, Affirmative Action, and Racial Attitudes, In: Danziger, S. H., Sandefur, G. D. \& Weinberg, D. H. (eds.) Confronting Poverty: Prescriptions for Change (New York: Russell Sage Foundation; Cambridge, MA: Harvard University Press).

Boehmke, F. J. \& Witmer, R. (2004) Disentangling Diffusion: The Effects of Social Learning and Economic Competition on State Policy Innovation and Expansion, Political Research Quarterly, 57 (1), pp. 39-51.

Busenberg, G. J. (2001) Learning in Organizations and Public Policy, Journal of Public Policy, 21 (2), pp. 173-189.

Carpenter, D. P. (2002) Groups, the Media, Agency Waiting Costs, and FDA Drug Approval, American Journal of Political Science, 46 (3), pp. 490-505.

Cancian, M. \& Meyer, D. R. (2004) Alternative Measures of Economic Success among TANF Participants: Avoiding Poverty, Hardship, and Dependence on Public Assistance, Journal of Policy Analysis and Management, 23 (3), pp. 531-548.

Cohen, M. D. \& Sproull, L. S. (eds.) (1995) Organizational Learning (Thousands Oaks, CA: Sage Publishing).

Conlan, T. (1998) From New Federalism to Devolution: Twenty Five Years of Intergovernmental Reform (Washington, DC: Brookings Institution Press).

Cooke, P. \& Alexander, W. (2000) In-Depth Report: Caldwell, North Carolina, Retrieved October 15, 2001, from the Tracking County Responses to Welfare Reform Web site.

Cooke, P. W. \& Haithcock, S. (2002) Welfare Reform in North Carolina: The Reinvention of Local Administration, In: Kelleher Palus, C. \& Webb Yackee, S. (eds.) Meeting Challenges: North Carolina Responds to Welfare Reform, 1996-2001 (Chapel Hill, NC: The School of Government Press).

Curtice, J. (2006) A Stronger or Weaker Union? Public Reactions to Asymmetric Devolution in the United Kingdom, Publius: The Journal of federalism, 36 (1), pp. 95-113, doi: 10.1093/publius/pjj006.

Danziger, S., Heflin, C. M., Corcoran, M. C., Oltmans, E. \& Wang, H. C. (2002) Does It Pay to Move from Welfare to Work?, Journal of Policy Analysis and Management, 21 (4), pp. 671-692.

DeHoog, R. H. \& Mattiello, J. (2001) In-Depth Report: Forsyth, North Carolina, Retrieved October 15, 2001, from the Tracking County Responses to Welfare Reform Web site.

Eckstein, H. (1992) Case Studies and Theory in Political Science, In: Eckstein, H. (ed.) Regarding Politics: Essays on Political Theory, Stability, and Change (Berkeley, CA: University of California Press), doi: 10.1007/BF02687130. 
Eggers, W. \& O'Leary, J. (1995) Revolution at the Roots: Making Our Government Smaller, Better and Closer to Home (New York, NY: Free Press).

Fellowes, M. C. \& Rowe, G. (2004) Politics and the New American Welfare States, American Journal of Political Science, 48 (2), pp. 362-373.

Ferejohn, J. A. \& Weingast, B. R. (eds.) (1997) The New Federalism: Can the States Be Trusted? (Stanford, CA: Hoover Institution Press).

Fording, R., Schram, S. F. \& Soss, J. (2005) The Color of Devolution: The Politics of Local Punishment in the New World of Welfare, paper presented at the American Political Science Association Conference, Washington D.C.

Gainsborough, J. F. (2003) To Devolve or Not To Devolve? Welfare Reform in the States, Policy Studies Journal, 31 (4), pp. 603-623, doi: 10.1111/1541-0072.00045.

Gallup-Black, A. (1998) Federalism, Policy Innovation, and Welfare Reform in the American States, Ph.D. Dissertation (New York: Columbia University).

Garand, J. C. \& Hendrick, R. M. (1991) Explaining Tradeoffs in the American States: A Longitudinal Test, 1948-1984, The Western Political Quarterly, 44 (4), pp. 915-940, doi: $10.1177 / 106591299104400407$.

Garman, C., Haggard, S. \& Willis, E. (2001) Fiscal Decentralization: A Political Theory with Latin American Cases, World Politics, 53 (2), pp. 205-236.

Gilens, M. (1999) Why Americans Hate Welfare: Race, Media, and the Politics of Antipoverty Policy (Chicago, IL: University of Chicago Press).

Gueron, J. M. (1998) A Research Context for Welfare Reform, Journal of Policy Analysis and Management, 15 (4), pp. 547-561.

Heclo, H. (1974) Modern Social Politics in Britain and Sweden: From Relief to Income Maintenance (New Haven, CT: Yale University Press).

Hughes, M. A. (1998) Learning from the 'Milwaukee Challenge, Journal of Policy Analysis and Management, 15 (4), pp. 562-571.

Jacoby, W. (1994) Public Attitudes toward Government Spending, American Journal of Political Science, 38 (2), pp. 336-361.

Jeffery, C. (2006) Devolution and Local Government, Publius: The Journal of Federalism, 36 (1), pp. 57-73, doi: 10.1093/publius/pij009.

Jeffery, C. \& Wincott, D. (2006) Devolution in the United Kingdom: Statehood and Citizenship in Transition, Publius: The Journal of Federalism, 36 (1), pp. 3-18, doi: 10.1093/publius/pjj014.

Kenyon, D. A. \& Kincaid, J. (eds.) (1991) Competition Among States and Local Governments: Efficiency and Equity in American Federalism (Washington, DC: Urban Institute Press).

Kincaid, J. (1998) The Devolution Tortoise and the Centralization Hare, New England Economic Review, May/June, pp. 13-40.

Kindgon, J. (1995) Agendas, Alternatives, and Public Policies (New York: Addison-Wesley Educational Publishers, Inc.).

Landy, M. \& Teles, S. M. (2001) Beyond Devolution: From Subsidiarity to Mutuality, In: Nicolaidis, K. \& Howse, R. (eds.) The Federal Vision (Oxford: Oxford University Press).

Levy, J. S. (1994) Learning and Foreign Policy: Sweeping a Conceptual Minefield, International Organizations, 48 (2), pp. 279-312.

Lieberman, R. C. \& Shaw, G. M. (2000) Looking Inward, Looking Outward: The Politics of State Welfare Innovation under Devolution, Political Research Quarterly, 53 (2), pp. 215-240.

Loeb, S. \& Corcoran, M. (2001) Welfare, Work Experience, and Economic Self-Sufficiency, Journal of Policy Analysis and Management, 20 (1), pp. 1-20.

Lupia, A. \& McCubbins, M. D. (1994) Designing Bureaucratic Accountability, Law and Contemporary Problems, 57 (1-2), pp. 91-126.

May, P. J. (1992) Policy Learning and Failure, Journal of Public Policy, 12 (4), pp. 331-354. 


\section{LEX LOCALIS - JOURNAL OF LOCAL SELF GOVERNMENT \\ S. Webb Yackee \& C. Kelleher Palus: Learning from Experience? Second-Order Policy \\ Devolution and Government Responsiveness}

Maddala, G. S. (1971) The Use of Variance Components Models in Polling Cross Section and Time Series Data, Econometrica, 39 (2), pp. 341-358.

Mettler, S. (2000) States' Rights, Women's Obligations: Contemporary Welfare Reform in Historical Perspective, Women \& Politics, 21 (1), pp. 1-33, doi: 10.1300/J014v21n01_01.

Meyers, M. K., Riccucci, N. M. \& Lurie, I. (2001) Achieving Goal Complexity in Complex Environments: The Case of Welfare Reform, Journal of Public Administration Research and Theory, 11 (2), pp. 165-201.

Mitchell, J. (2006) Evolution and Devolution: Citizenship, Institutions, and Public Policy, Publius: The Journal of Federalism, 36 (1), pp. 153-168.

Mohr, L. B. (1969) Determinants of Innovations in Organizations, American Political Science Review, 63 (1), pp. 111-126.

Mossberger, K. \& Hale, K. (2002) Polydiffusion in Intergovernmental Programs: Information Diffusion in the School-to-Work Network, American Review of Public Administration, 32 (4), pp. 398-422.

Murray, C. (1984) Losing Ground: American Social Policy, 1950-1980 (New York, NY: Basic Books).

Nerlove, M. (1971) Further Evidence on the Estimation of Dynamic Economic Relations from a Time Series of Cross Sections, Econometrica, 39 (2), pp. 359-382.

O'Neill, K. (1999) Decentralization in the Andes: Power to the People or Party Politics?, Ph.D. Dissertation (Cambridge, MA: Harvard University).

Osborne, D. (1988) Laboratories of Democracy (Boston: Harvard Business School Press).

Peterson, P. (1981) City Limits (Chicago: The University of Chicago Press).

Peterson, P. (1995) The Price of Federalism (Washington, D.C., Brookings Institution Press).

Peterson, P. \& Rom, M. C. (1990) Welfare Magnets: A New Case for a National Standard (Washington, D.C., Brookings Institution Press).

Peterson, P. E. \& Rom, M. (1989) American Federalism, Welfare Policy, and Residential Choices, The American Political Science Review, 83 (3), pp. 711-728.

Raimondo, H. J. (1996) State Budgeting: Problems, Choices, and Money, In: VanHorn, C. E. (ed.) The State of the States (3rd Edition) (Washington, D.C.: CQ Press).

Rassel, G. \& Etringer, B. (2000) In-Depth Report: Cabarrus, North Carolina, Retrieved October 15, 2001, from the Tracking County Responses to Welfare Reform Web site.

Rom, M. C. (2005) Are the States Effective Laboratories of Democracy?, paper presented at the American Political Science Association Conference, Washington D.C.

Rosenthal, D. B. \& Hoefler, J. M. (1989) Competing approaches to the study of American federalism and intergovernmental relations, Publius: The Journal of Federalism 19 (1), pp. 1-23.

Sabatier, P. A. (1987) Knowledge, Policy-Oriented Learning, and Policy Change, Science Communication, 8 (4), pp. 649-692.

Sabatier, P. A. (1988) An Advocacy Coalition Framework of Policy Change and the Role of Policy-Oriented Learning Therein, Policy Sciences, 21 (2-3), pp. 129-168.

Sawyer, G. (1969) Modern Federalism (London: Watts).

Sayrs, L. W. (1989) Pooled Time Series Analysis (Newbury Park, CA: Sage Publications).

Scavo, C. (2000) In-Depth Report: Craven, North Carolina, Retrieved October 15, 2001, from the Tracking County Responses to Welfare Reform Web site.

Scully, R., Jones, R. W. \& Tyrstan, D. (2004) Turnout Participation and Legitimacy in PostDevolution Wales, British Journal of Political Science, 34 (3), pp. 519-537.

Soss, J., Sanford, F. S., Vartanian, T. P. \& O’Brien, E. (2001) Setting the Terms of Relief: Explaining State Policy Choices in the Devolution Revolution, American Journal of Political Science, 45 (2), pp. 378-395.

Tiebout, C M. (1956) A Pure Theory of Local Expenditures, Journal of Political Economy, 64, pp. 416-424, doi: 10.1086/257839. 
Volden, C. (1997) Entrusting the States with Welfare Reform, In: Ferejohn, J. \& Weingast, B. R. (eds.) The Few Federalism: Can the States be Trusted? (Stanford, CA: Hoover Institution Press).

Volden, C. (2006) States as Policy Laboratories: Emulating Success in the Children's Health Program, American Journal of Political Science, 50 (2), pp. 294-312.

Walker, D. B. (2000) The Rebirth of Federalism (New York: Seven Bridges Press).

Winston, P. (2002) Welfare Policymaking in the States (Washington, D.C.: Georgetown University Press).

Wright, D. S. (1988) Understanding Intergovernmental Relations, 3rd Edition (Monterey, CA: Brooks/Cole Press). 